\section{Human Behavioral Changes and ItS IMPACt IN DISEASE MODELING}

Teoh Shian Li*, Jane Labadin, Phang Piau, Ling Yeong Tyng, Shapiee Abd Rahman

Department of Computational Science and Mathematics, Faculty of Computer Science and Information Technology, Universiti Malaysia Sarawak, 94300, Kota Samarahan, Sarawak, Malaysia.
Article history

Received

15 July 2015

Received in revised form

1 October 2015

Accepted

25 October 2015

*Corresponding author shianli90@gmail.com

\section{Graphical abstract}

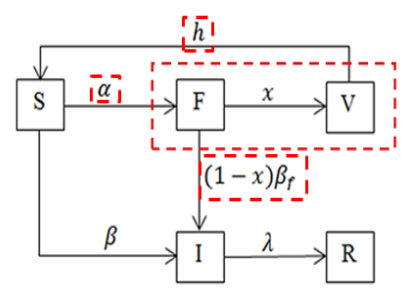

\begin{abstract}
One of the threats of the world health is the infectious diseases. This leads to the raise of concern of the policymakers and disease researchers. Vaccination program is one of the methods to prevent the vaccine-preventable diseases and hence help to eradicate the diseases. The impact of the preventive actions is related to the human behavioral changes. Fear of the diseases will increase one's incentive in taking the preventive actions to avoid the diseases. As human behavioral changes affecting the impact of the preventive actions, the individual-based model is constructed to incorporate the behavioral changes in disease modeling. The agents in the individual-based model are allowed to move randomly and interact with each other in the environment. The interactions will cause the disease viruses as well as the fearfulness to be spread in the population. In addition, the individual-based model can have different environment setups to distinguish the urban and rural areas. The results shown in this paper are divided into two subsections, which are the justification of using uniform distribution as random number generator, and the variation of disease spread dynamics in urban and rural areas. Based on the results, the uniform distribution is found to be sufficient in generating the random numbers in this model as there is no extreme outlier reported in the experiment. We have hypothesized the individuals in urban area to have higher level of fearfulness compared to those in rural area. However, the preliminary results of the survey conducted show a disagreement with the hypothesis. Nevertheless, the data collected still show two distinct classes of behavior. Thus, the distinction does not fall into the samples taken from rural or urban areas but perhaps more on the demographic factors. Therefore, the survey has to be study again and demographic factors have to be included in the survey as we could not distinguish the level of fearfulness by areas.
\end{abstract}

Keywords: Infectious diseases; individual-based model; human behavioral changes; vaccination decision; level of fearfulness

\begin{abstract}
Abstrak
Salah satu ancaman kesihatan dunia adalah penyakit jangkitan. Ini menyebabkan kesedaran dari pihak berkuasa dan penyelidik penyakit telah ditinggikan. Program vaksinasi adalah salah satu kaedah untuk mencegah penyakit-penyakit jangkitan yang dapat dicegah melalui vaksin dan dengan itu membantu untuk membasmi penyakit. Kesan tindakan pencegahan penyakit adalah berkaitan dengan perubahan tingkah laku manusia. Ketakutan terhadap penyakit akan meningkatkan insentif seseorang untuk mengambil langkah-langkah pencegahan untuk mengelakkan penyakit. Disebabkan perubahan tingkah laku manusia akan menjejaskan kesan tindakan pencegahan, individual-based model dibina untuk menerapkan perubahan tingkah laku dalam pemodelan penyakit. Ejen-ejen dalam individual-based model dibenarkan untuk bergerak secara rambang dan berinteraksi antara satu sama lain dalam alam sekitar model. Interaksi akan menyebabkan virus penyakit serta ketakutan individu disebarkan
\end{abstract}

